Abstracta Iranica Abstracta Iranica

Revue bibliographique pour le domaine irano-aryen

Volume 28 | 2007

Comptes rendus des publications de 2005

\title{
Sufi Commentaries on the Qur'an in Classical Islam. New York, Routledge, 2005, 196 p.
}

\section{Pierre Lory}

\section{(2) OpenEdition}

1 Journals

\section{Édition électronique}

URL : http://journals.openedition.org/abstractairanica/13172

DOI : 10.4000/abstractairanica. 13172

ISSN : 1961-960X

Éditeur:

CNRS (UMR 7528 Mondes iraniens et indiens), Éditions de l'IFRI

\section{Édition imprimée}

Date de publication : 15 mai 2007

ISSN : 0240-8910

Référence électronique

Pierre Lory, «Sufi Commentaries on the Qur'an in Classical Islam. New York, Routledge, 2005, 196 p. », Abstracta Iranica [En ligne], Volume 28 | 2007, document 290, mis en ligne le 18 septembre 2007,

consulté le 25 septembre 2020. URL : http://journals.openedition.org/abstractairanica/13172 ; DOI : https://doi.org/10.4000/abstractairanica.13172

Ce document a été généré automatiquement le 25 septembre 2020.

Tous droits réservés 


\section{Sufi Commentaries on the Qur'an in Classical Islam. New York, Routledge, 2005, 196 p.}

Pierre Lory

Résultat d'une recherche doctorale, ce travail expose d'abord les principes de l'herméneutique en Islam, avec des références comme Ṭabarī et Ġazālī en particulier (parmi bien d'autres exégètes) avant de décrire les différentes démarches exégétiques des auteurs mystiques classiques. Puis elle passe à une série plus précise d'exemples de commentaires chez des exégètes littéralistes comme mystiques (notamment des versets III 7 ou XXIV 35). Si cette œuvre balaie de façon forcément assez panoramique le champ d'œuvres immenses et des périodes très éloignées les unes des autres, elle n'en donne pas moins des éclairages très précieux sur un domaine encore mal balisé des sciences religieuses musulmanes, grâce à une érudition très sûre et une connaissance toujours précise des textes cités.

INDEX

Thèmes : 8 . Soufisme

\section{AUTEURS}

PIERRE LORY

EPHE - Paris 